\title{
Erratum to: Pilot and feasibility study: prospective proteomic profiling of mammary epithelial cells from high-risk women provides evidence of activation of pro-survival pathways
}

\author{
Catherine Ibarra-Drendall · Michelle M. Troch - William T. Barry • \\ Gloria Broadwater · Emanuel F. Petricoin III - Julia Wulfkuhle • \\ Lance A. Liotta - Siya Lem · Joseph C. Baker Jr. • Anne C. Ford • \\ Lee G. Wilke • Carola Zalles • Nicole M. Kuderer • Abigail W. Hoffman • \\ Melanie Shivraj · Priya Mehta · Jamila Williams • Nora Tolbert • \\ Laurie W. Lee $\cdot$ Patrick G. Pilie $\cdot$ Dihua Yu $\cdot$ Victoria L. Seewaldt
}

Published online: 31 August 2012

(C) Springer Science+Business Media, LLC. 2012

Erratum to: Breast Cancer Res Treat (2012) 132:487-498 DOI 10.1007/s10549-011-1609-9

Unfortunately, the authors have inadvertently not acknowledged one of their funding supports in the original publication of the article. The authors would like to credit the Department of Defense Award W81XWH-09-1-0063 in funding this work (C. Ibarra-Drendall, V.L. Seewaldt).

The online version of the original article can be found under doi:10.1007/s10549-011-1609-9.

C. Ibarra-Drendall $(\bowtie) \cdot$ M. M. Troch $\cdot$ S. Lem .

J. C. Baker Jr. · N. M. Kuderer · A. W. Hoffman · M. Shivraj ·

P. Mehta $\cdot$ J. Williams $\cdot$ N. Tolbert $\cdot$ L. W. Lee

P. G. Pilie · V. L. Seewaldt

Division of Medical Oncology, Duke University Medical Center, Box 2628, Durham, NC 27710, USA

e-mail: ibarr001@mc.duke.edu

W. T. Barry · G. Broadwater

Department of Biostatistics \& Bioinformatics, Duke University

Medical Center, Durham, NC 27710, USA

E. F. Petricoin III · J. Wulfkuhle $\cdot$ L. A. Liotta

Center for Applied Proteomics and Molecular Medicine, George

Mason University, Manassas, VA 20110, USA

A. C. Ford

Department of Obstetrics and Gynecology, Duke University

Medical Center, Durham, NC 27710, USA

\author{
L. G. Wilke \\ Division of General Surgery, University of Wisconsin, Madison, \\ WI 53792, USA \\ C. Zalles \\ Texas A\&M Health Sciences Center, College of Medicine, \\ Round Rock, TX 78665, USA \\ D. $\mathrm{Yu}$ \\ Department of Molecular and Cellular Oncology, MD Anderson \\ Cancer Center, Houston, TX 77030, USA
}

